\title{
Some Aspects at the Formation in Engineering: The Curriculum by Competitions and the Curriculum Socio-Critic ${ }^{*}$
}

\author{
Jaime Espinoza Oyarzún \\ University of Santiago of Chile (USACH), Santiago, Chile
}

\begin{abstract}
This paper discusses some aspects of the training of engineers, showing two different approaches, the skills approach and socio-critical approach and how they are possible to be integrated in such a way to bring their potential to the formation of this professional, considering the challenges the future.
\end{abstract}

Keywords: engineer, competitions, socio-critical

\section{Introduction}

Science and technology have had a steady and sustained progress in the past five decades, causing a strong impact on human activities.

In turn, the work field has felt the impact as education; it has been forced to introduce major changes to meet the needs of companies to have qualified human resources and advanced.

UNESCO, through the Delors (1994) Report and other documents (Magendzo, 2006; Faure, 1973; UNESCO, 1990, 2000) and others (Prelac, 2002; Cres, 2008) have introduced the concept of lifelong learning and have added that education is a highly relevant and inalienable right, whose purpose is the integral development of individuals.

Skills training have been one of the ways in which education has faced the needs of the workplace. This stems from the world of work and has been adopted by many institutions of higher education as a model for engineering education.

Skills training are a curricular approach among its qualities shows job training, based on a look at the productive sectors resulting in the relevance of the curriculum, but relativizing humanist education (Schink \& Ormeño, 2006), which has preoccupied the academic world by the emergence of neoliberal thinking, leading to other more humanistic approaches.

In this context, the socio-critic curriculum appears as opposed to curriculum competencies, which promotes the transformation of society through a reflective-critical transformation, humanizing, which gives an emphasis on the role of education and curriculum content, attaches importance to the student as an agent of change and shows a social vision of the school.

\section{Methodology}

From Engineering Congress 2014, held in Buenos Aires in which UNESCO guidelines for engineering

\footnotetext{
${ }^{*}$ The paper was published by the Program Book at the First International Conference on Higher Education Advances, Spain, 2015.

Jaime Espinoza Oyarzún, Professor of Chemistry, University of Santiago of Chile (USACH).
} 
education arise from the concern arises 2015 by entering into this topic. Starts collecting information, interviews with professionals from the University of Santiago of Chile, curriculum specialists and engineering, review of official electronic information from some universities. Then, analyzed and studied the information is applicable to the preparation of this work, including its conclusions.

\section{Objectives}

The objectives of this papers are as followes:

(1) To demonstrate the possibility to apply the socio-critic curriculum in training engineer.

(2) To analyze the advantages and disadvantages of both approaches in engineering training.

\section{Antecedents}

The University of Santiago of Chile (USACH) is a state institution of higher education and public which, among its many degrees, dictates Engineering with two different approaches: competency in the Faculty of Engineering (Letelier et al., 2005) and linear curriculum Faculty of Technology.

Currently, the skills approach is recurrent in the current training of engineers, paradigmatic in many universities. The reference document presents a sustainable system for engineering skills training; only mentions training for work and not considered an important aspect as the integral formation that allows the student to be a critical professional and dutiful to society.

\section{The Curriculum}

Within the curricular concepts, one of the most important approaches has raised Shirley Grundy (1992). It argues that the curriculum is a cultural concept that reflects what society tries to reproduce in the new generations. In this conception, the skills approach corresponds to a technical curriculum characterized in that the objectives are predefined by the company; the idea of curriculum, reflected in the plans and programs of study, before the educational activity; the organization, based on the ability of the teacher and the teaching action as a product giving searched learning in students. In this approach, the task of theory serves the efficient achievement of operational objectives; practice only exists in relation to compliance with certain plans.

Today, the conceptualizations of competencies point to perform the action, experience and performance context as key in such conceptualizations. The trend is that the powers integrate theory and practice that it solves everyday problems but as well how emergent problems, atypical or rare in the engineer applies a repertoire of knowledge and skills that allow you to be smart against a given situation. This concept involves a concatenation of knowledge that not only articulates a conception of being, knowledge, know-how and knowledge to live, or put another way, involves pragmatic knowledge and knowledge production oriented.

In relation to engineering education, this approach allows the engineer is able to solve problems in different contexts, whether professional or cultural; combining training and work cycles; self-learning; ability to respond quickly to new everyday problems; integrate and reconvert skills; to put in practice the capabilities of mathematical-abstract and reflection to develop initiative, creativity, innovation and decision-making ability logical thinking.

On the other hand, advantages of this approach are the effective linkage between business and universities, training in various sociocultural contexts, continuous updating of curricula and study programs, learning through electronic media, facilitating the integration and better learning assessment. 
This approach is also possible to mention disadvantages. Including interference neoliberal economic model that prioritizes the needs of the companies of the country, there is a limitation of control and autonomy of teachers in the development and implementation of learning, poor training in the social and human level, creates unmet demands on workers.

\section{Curriculum Socio-Critic}

Socio-Critical Theory meets a set of theories from different fields of thought whose purpose is to look at reality from a revolutionary and transformative view, for it seeks to transform the world. Within this concept USACH motto is inscribed, "Educating people to transform the country".

Curricularly, postulates that the basic values to develop are the shared values, cooperative, shared in common and liberating. The contents must be socially meaningful and the constructive activities and shared learning activities. The relation between theory and practice is inseparable from this contradiction in the facts and situations; practice is the theory in action. The fixation of objectives is made through dialogue and discussion among students. It considers that the official curriculum is an instrument of reproduction of power. There are primacy of teamwork within the school and its environment. The teacher's role should be considered reflective, critical, transformative agent of social change, a researcher in the classroom, committed to the education of students and the socio-political situation.

\section{Analysis}

Performing a curriculum redesign involves a profound changes; especially if it is passed from a still persistent, a curriculum by competencies and even more if it is a socio-critical curriculum, somewhat unknown linear curriculum.

In engineering, it is very important training in basics science; they provide solid and broad foundation for the basic technological development of professional performance. The formation in basic science, based on the transmission of knowledge, is shaped suitably in the linear curriculum, therefore the formation in sciences of engineering and specific technologies can be developed according to various curricular approaches.

It is necessary to mention that the engineer can perform in varied professional and cultural contexts, different areas of performance and complex situations, dysfunctional situations and emerging contexts. This means that a curriculum hardly can shape the variety of skills that the professional can develop. All the engineering competitions essentially point at the technology, relativizing the integral formation, which is the ultimate goal of education.

In a curriculum which foster the integral development engineer taking skills training as an axis, it would be advisable to exercise gradually, through the hidden curriculum, introducing elements of socio-critical curriculum, integrating the qualities of both approaches. Incorporate skills for development of critical thinking, related to moral discernment, to live and understand, to issue ethical and aesthetic judgments and to express itself adequately in their mother tongue. In this regard, the prominent educator Ms. Viola Soto (2004) believes that educational policy should advocate training that "On the one hand, a caring man looking in continuing cooperation with others, with a story based on which builds its vision and its entry into the planetary civilization; otherwise, a competitor individual, able to deny the presence of others or separate their benefit, whose north is the future of techno-scientific 'globalization"”. 
The success in the implementation of a curriculum as the indicated will be difficult and slow, we should have a natural resistance to change. Teachers with initial training that does not comply with the principle of "reflective practitioner" (Schön, 1992), and they should: (1) guide training in the learning-development axis; (2) approach the theory and the daily practice, incorporating service-learning methodology; and (3) joint training levels that enable effective training itinerary. Besides, universities should provide quality education with an innovative multidisciplinary management by incorporating a culture of change and continuous quality improvement; and ensure sufficient costs for students' practice financial resources.

These concepts are shaped the recommendations of UNESCO (Brito, 2014) in the Agenda for the Development after 2015.

In Chile, some universities declare skills training, including, secondarily, social skills, but a simple analysis of information on the official websites of these schools, enough to realize that the stated curriculum is linear, either, traditional no indication of socio-critical curriculum (U de Chile, 20015; U of Talca, 2015; U de la Frontera, 2015). They all agree on issues such as ethics, social responsibility, oral and written communication incorporated as subjects with no more than two hours a week. Moreover, a study conducted at the National Technological University of Argentina shows the difficulty of incorporating, as elements of social skills and personal development. The authors, among its recommendations point to the increase in social science subjects (Ferrando \& Páez, 2009).

\section{Conclusions}

The competency-based approach has gained ground in engineering education with the strong support of the prevailing neoliberal system and international organizations, but it should be stressed that the linear engineering, traditional approach still remains and, in some colleges the approach competences not pass rather than being a statement. If deemed central to the curriculum competency axis, facing a socio-critical approach, it is advisable to integrate the best of both concepts in order to develop and implement a curriculum that ensures competency-based training, which is based on the engineering training that will lead to a comprehensive education, implying an engineer with technological and scientific training at the highest level, with a high sense of social responsibility and a marked development of critical and reflective thinking and skills issue argued and ethical judgments, that places engineering in central finding solutions for sustainable development and promote a more integrated and collaborative research (Ferrando \& Páez, 2009).

\section{References}

Brito, L. (2014). Ciencia y sustentabilidad global: Desafios para la educación Superior. Ingeniería 2014, Latinoamérica y Caribe. Congreso y Exposición. Buenos Aires. Retrieved from www.cai.org.ar/index.php/biblioteca-Ing2014/ponencias

Cres. (2008). Declaración de la Conferencia Regional de la Educación Superior en América Latina y el Caribe. Retrieved from www.cres2008.org/es/index.php

Cres. (2008). Declaración de la Conferencia Regional de la Educación Superior en América Latina y el Caribe.Delors, J. (1994). La Educación Encierra un Tesoro. Informe a la Unesco de la Comisión Internacional sobre Educación para el Siglo XXI. UNESCO.

Fauré, E. (1973). Aprender a Ser; la Educación del Futuro. Comisión Internacional sobre el Desarrollo de la Educación, UNESCO.

Ferrando, K. C., \& Páez, O. H. (2009). Formación de Ingenieros: Un análisis reflexivo desde los estudios sociales de la Ciencia y la Tecnología. Facultad Regional Avellaneda, Universidad Tecnológica Nacional. Retrieved from www.coini.com.ar/COINI2009/contenidos/FORMACION_DE_INGENIEROS.pdf

Grundy, S. (1992). Producto o praxis del currículum. Editorial Morata. 
Letelier, M. et al (2005). Sistema de Competencias Sustentables para el Desempeño Profesional en Ingeniería. CICES, USACH. Revista de la Facultad de Ingeniería Universidad de Tarapacá. Vol. 13, № 2.

Magendzo, A. (2006). El Derecho a una Educación, a una Educación de Calidad con Equidad para Todos: el Ejercicio de un Derecho Humano. Diario de la Sociedad Civil.

Prelac. (2002). Un Trayecto Regional hacia la Educación para Todos. La Habana.

Schink, H., \& Ormeño, E. (2006). Hacia un concepto de formación de personas competentes. Revista Intramuros, No 17. Universidad Metropolitana de Ciencias de la Educación.

Schön, D. (1992). La formación de profesionales reflexivos. Paidós.

Soto, V. (2004). Politicas, acciones curriculares y reforma de la educación en Chile. Universidad Metropolitana de Ciencias de la Educación. Retrieved from www.colegiodeprofesores.cl/congreso/viola_soto.htm

UNESCO. (1990). Declaración Mundial sobre Educación para Todos y Marco de Acción para Satisfacer las Necesidades Básicas de Aprendizaje. Jomtien, Tailandia.

UNESCO. (2000). Educación para Todos: Cumplir Nuestros Compromisos Comunes. Foro Mundial sobre Educación para Todos. Dakar, Senegal.

U DE Chile. (2015). Retrieved from www.ingenieria.udechile.cl/carreras

U de la Frontera. (2015). Retrieved from www.admision.ufro.cl/index.php/ver-carreras

U de Talca. (2015). Retrieved from www.udetalca.cl/link.cgi/carreraspregrado 